Case Report

\title{
Angiomyolipoma; a rare entity in the left adrenal gland
}

\author{
Shankar Bastakoti1 ${ }^{1}$ Binay Thakur ${ }^{2}$, Mukti Devkota ${ }^{2}$, Amrita Paudel $^{3}$ \\ ${ }^{\prime}$ Department of Pathology, B.P. Koirala Memorial Cancer Hospital, Bharatpur, Chitwan, Nepal. \\ ${ }^{2}$ Department of Surgery, B.P. Koirala Memorial Cancer Hospital, Bharatpur, Chitwan, Nepal. \\ ${ }^{3}$ Department of Public Health, Chitwan Medical College, Chitwan, Nepal.
}

\section{Keywords:}

Adrenal; Angiomyolipoma;

Lipoma;

\section{ABSTRACT}

Adrenal angiomyolipoma is a rare benign entity and only to sixteen cases have been reported in English literature till date. Other site of occurrence is liver, spleen, lungs, bone and ovary. We report a female aged 54 years, who presented with left flank pain, on CT scan showed left adrenal mass. Patient underwent laparoscopic adrenalectomy and final histopathological examination revealed angiomyolipoma of left adrenal gland.

\section{Correspondence:}

Dr.Shankar Bastakoti, MD

Registrar, Department of Pathology,

B.P. Koirala Memorial Cancer Hospital, Bharatpur, Chitwan, Nepal. ORCID ID: 0000-0002-0446-1440

Email:drshankarbastakoti@gmail.com

Reveived : May 25 2018 ; Accepted : August $2^{\text {nd }} 2018$; Published : September $1^{\text {st }} 2018$

Citation: Bastakoti S, Thakur B, Devkota M, Paudel A. Angiomyolipoma; A rare entity in the Left adrenal gland. J Pathol Nep 2018;8: 1416-18. DOI: 10.3126/jpn.v\%vi\%i.20897

Copyright: This is an open-access article distributed under the terms of the Creative Commons Attribution 4.0 International License, which permits unrestricted use, distribution, and reproduction in any medium, provided the original author and source are credited.

\section{INTRODUCTION}

Adrenal angiomyolipoma is very rare entity. Only 16 cases have been reported so far in English literature. ${ }^{1}$ Angiomyolipoma is apparently a part of a family of neoplasms that derive from perivascular epithelioid cells. It is a rare mesenchymal tumor, usually found in the kidney. Extrarenalangiomyolipoma is uncommon, and the most common extrarenal site is the liver. ${ }^{2}$ Here, we present a case of adrenal gland angiomyolipoma in a 54 year female.

\section{\#CASE REPORT}

A 54-year female presented with complaint of non-specific pain in left flank for last three and half years. She was under medical treatment for essential hypertension and hypothyroidism. Biochemical examinations including blood urea, serum creatinine and serum metanephrin were within normal limit. On Contrast enhanced CT scan of abdomen, a well-defined non-enhancing fat attenuating mass lesion $8 \times 7 \times 6 \mathrm{~cm}$ was noted in left adrenal gland. The mass was abutting the superior surface of left kidney. Patient underwent laparoscopic left adrenalectomy. Histopathological examination showed single nodular thin capsulated mass 


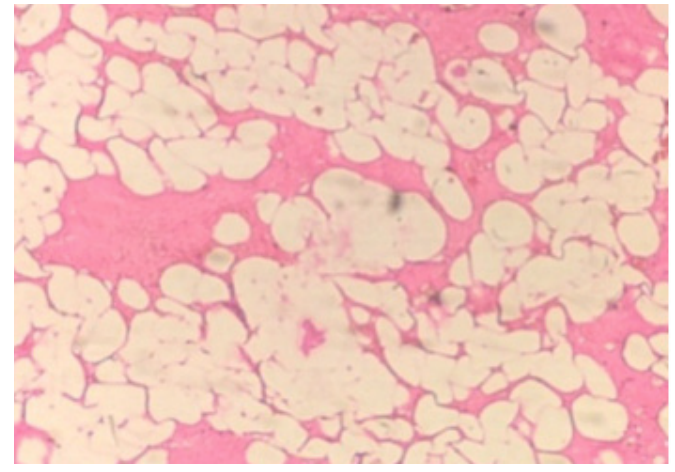

Figure 1: Photomicrograph showing adipocytes, few vessels and interspersed smooth muscle bundle.(HE stain, X100).

measuring $8 \times 6 \mathrm{~cm}$.Cut section revealed yellowish fatty areas with hemorrhagic areas as well. Microscopic examination exhibited abundant areas of adipose tissue with interspersed varying sized capillary vessels and at places muscle bundle as well.(fig.1) Compressed adrenal gland structures were also seen. (fig.2) The histological picture was consistent with Angiomyolipoma (fig. 1,2).

\section{DISCUSSION}

Lipomatous tumor of adrenal gland accounts for $5 \%$ of primary adrenal tumor. It comprises of myelolipoma, teratoma, lipoma, angiomyolipoma and liposarcoma. They usually present with nonspecific flank pain or may be totally incidental. The most catastrophic presentation includes retroperitoneal hemorrhage from the tumor because of friable blood vessels. Options for treatment include tumor excision, angioembolization or chemotherapy. ${ }^{3,4}$

Angiomyolipoma of adrenal is extremely rare entity; the diagnosis is based on CT scan and histopathological findings. The later shows relative proportions of fat, smooth muscle,

Table 1: Case of angiomyolipoma reported in literature.

\begin{tabular}{|c|c|c|}
\hline Author/year/country & Sex/age & Site \\
\hline Lam et al /2001/ Hongkong ${ }^{3}$ & $\mathrm{~F} / 46$ & Left \\
\hline Elsayes et al $/ 2005 /$ USA $^{7}$ & $\mathrm{~F} / 49$ & Right \\
\hline Godara et al $/ 2007 /$ India $^{2}$ & $\mathrm{~F} / 45$ & Left \\
\hline Sutter et al /2007/ Switzerland ${ }^{8}$ & $\mathrm{~F} / 32$ & Right \\
\hline D'Antonio et al /2009/ Italy9 & $\mathrm{M} / 42$ & Left \\
\hline Chee K et al /2010/ Malaysia ${ }^{10}$ & $\mathrm{M} / 61$ & Left \\
\hline Yener et al /2011/ Turkey ${ }^{1}$ & $\mathrm{~F} / 45$ & Right \\
\hline Hu et al /2012/ China ${ }^{11}$ & $\mathrm{~F} / 55$ & Right \\
\hline Hafeez B et al /2012/ Pakistan ${ }^{12}$ & $\mathrm{~F} / 72$ & Right \\
\hline Sazuka et al /2013/ Japan ${ }^{13}$ & $\mathrm{~F} / 68$ & Right \\
\hline Goswami et al /2014/ India ${ }^{6}$ & $\mathrm{~F} / 43$ & Right \\
\hline Zhao et al $/ 2014 /$ China $^{14}$ & $\mathrm{~F} / 47$ & Left \\
\hline Li et al $/ 2015 /$ China $^{15}$ & $\mathrm{M} / 53$ & Left \\
\hline Kwazneski et al /2016/ USA ${ }^{16}$ & $\mathrm{~F} / 65$ & Right \\
\hline Present case & $\mathrm{F} / 54$ & Left \\
\hline
\end{tabular}

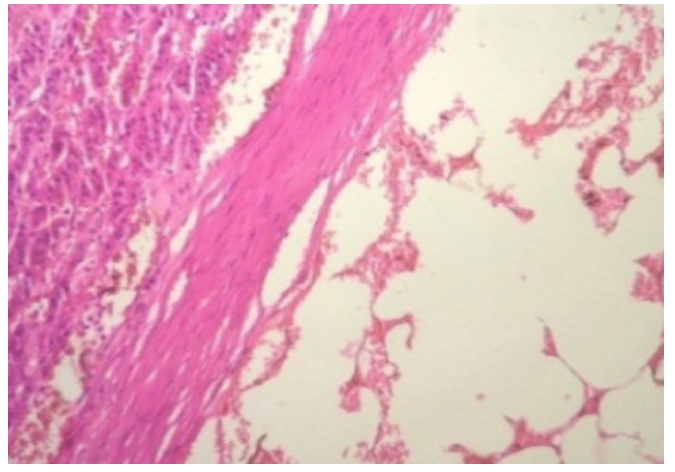

Figure 2: Photomicrograph showing adipocytes, thin fibrous capsule and compressed adrenal gland. (H E stain, X100).

and blood vessels. The smooth muscle component is also variable in appearance. A frequent finding is radial arrays of smooth muscle fibers about blood vessels and also is found in bundles and scattered as individual fibers. The blood vessels are often abnormal, with thick walls resembling those of arteries but with eccentrically placed or very small lumens. In cases with an extreme predominance of fat, angiomyolipoma can be confused with lipoma; extensive sampling may be necessary to identify the vascular and smooth muscle components of the tumor. Tumors with scant fat may be confused with other mesenchymal tumors, such as leiomyoma. Tumors with epithelioid features may mimic epithelial tumors. ${ }^{5}$ Similar cases have been reported and are shown in Table 1.

Since it is a benign disease, its prognosis is good. Nevertheless, follow-up is recommended because of atypical morphology. Currently, there is no agreed protocol on follow-up but an ultrasound of abdomen 3 to 6 months following the surgery with annual clinical examination for larger tumor is recommended. ${ }^{6}$

\section{CONCLUSION}

This is extremely rare benign adrenal gland tumor. However due to presence of angio-component hemorrhagic complication may occur. As health screening tools are increasingly used more cases are likely to be diagnosed in future. Histopathology gives the final diagnosis of angiomyolipoma comprising of adipocytes, smooth muscle cells and blood vessel.

\section{Conflict of Interest: None}

\section{REFERENCES}

1. Yener O, Özçelik A. Angiomyolipoma of the Right Adrenal Gland. ISRN Surg [Internet]. 2011;2011:1-2. Crossref

2. Godara R, Vashist M G, Singla SL, Garg P, Sen J, Mathur S K, Gupta A. Adrenal angiomyolipoma: A rare entity. Indian J Urol 2007;23:319-20. Crossref 
3. Lam KY, Lo CY. Adrenal lipomatous tumours: A 30 year clinicopathological experience at a single institution. J Clin Pathol. 2001;54:707-12. Crossref

4. Antar A, Boyle A, Patel T. Angiomyolipoma of the adrenal gland: a case presentation and a review of adrenal lipomatous tumors. Urol Case Rep 2017;12:59-61. Crossref

5. Christopher D. M. Fletcher. Diagnostic Histopathology of Tumors, 4th Edition. Elsevier Saunders, Philadelphia, 2013. 2296 P.

6. Goswami A, Sharma A, Khullar R, Soni V, Baijal M, Chowbey P. Adrenal angiomyolipoma: A case report and review of literature. $\mathrm{J}$ Minim Access Surg 2014;10:213-5. Crossref

7. Elsayes KM. Magnetic Resonance Imaging of adrenal angiomyolipoma. JCAT 2005;29:80-2. $\underline{\text { Crossref }}$

8. Sutter R, Boehler A, Willmann J. Adrenal angiomyolipoma in lymphangioleiomyomatosis. Eur Radiol 2007;17:565-6. Crossref

9. D'Antonio A, Caleo A, Caleo O, G DD, A B. Monotypic epithelioid angiomyolipoma of the adrenal gland: an unusual site for a rare. Ann Diagn Pathol 2009;13:347-50. Crossref

10. Kong CHC, Rose IM, Singam P, Hong GE, Cheok LB, Zainuddin ZM. Angiomyolipoma of the adrenal gland: A case report. Iran Red Crescent Med J. 2010;12:489-91.
11. $\mathrm{Hu} \mathrm{H,} \mathrm{Xi} \mathrm{X.} \mathrm{Giant} \mathrm{adrenal} \mathrm{angiomyolipoma.} \mathrm{J} \mathrm{Clin} \mathrm{Endocrinol}$ Metab. 2012;97:3835-6. Crossref

12. Hafeez Bhatti A, Dar F, Pervez M. Adrenal angiomyolipoma. J Coll Physicians Surg Pakistan 2013;23:663-4. $\underline{\text { Crossref }}$

13. Sazuka T, Takashi I, Takanobu U, Mitsuru Y, Kazuyoshi N. Angiomyolipoma in the adrenal region:adrenalectomy converted from laparoscopic to open laparotomy case. Japenese J Endourol 2013;26:135-7.

14. Zhao J, Sun F, Jing X, Zhou W, Huang X, Wang H, et al. The diagnosis and treatment of primary adrenal lipomatous tumours in chinese patients: A 31-year follow-up study. J Can Urol Assoc 2014;8:E1326. Crossref

15. Lam AK. Lipomatous tumours in adrenal gland: WHO updates and clinical implications. Endocr Relat Cancer. 2017;24:R65-79. Crossref

16. Kwazneski II D, Merrill M, Young J, Sell H. Angiomyolipoma and malignant PEComa: discussion of two rare adrenal tumors. Case Rep Oncol Med. 2016;2016:5204092. doi: 10.1155/2016/5204092. 